Iryna Martynenko, PhD (Candidate of Psychological Sciences), associate professor, Doctoral candidate, Department of Speech Disorders, National Pedagogical Dragomanov University, Pyrohova Str., 9, Kyiv, Ukraine

\title{
REFLECTION IN COMMUNICATION ACTIVITY OF PRESCHOOLERS WITH SYSTEM SPEECH DISORDERS
}

The article deals with reflexive difficulties in communication activity of senior preschoolers with system speech disorders. The author reviews theoretical background for reflection studies in psychology: from the standpoint of mental processes, intrapersonal formation, multiple processes phenomenon. According to the study reflection is interpreted by the author as a precondition for effective communication, while its deficit is considered to be the cause of various communication difficulties, operational ones, in particular. It has been discovered that reflection development process continues during the preschool age and senior preschoolers show certain prerequisites of reflexivity, which can be observed in different areas of their activity. Communication activity is one of the most meaningful and productive in this regard. In childhood reflection, as personality formation, depends on the extent of ability for self-analysis, self-expression and forecasting. Experimental data analysis on the communication activity of senior preschool age children with system speech disorders of primary genesis revealed difficulties in reflection of various activities: speaking, drawing and playing. The research on reflection of senior preschool age children with system speech disorders has been carried out by the means of observation and experimental study. The conducted experiments allowed to discover the following communication reflection difficulties faced by the children: difficulties of selfanalysis and self-observation, self-expression and self-improvement, and evaluating mutual activity results on their basis. Such difficulties in communication activity cause communication barriers for interactions with adults and peers, affect the interaction results. The described research has shown that difficulties of reflection impede communication interactions, indicate insufficient development of interactive communication skills. In this regard the further development of communication activity of senior preschoolers with system speech disorders should be carried out considering peculiarities not only in their communication skills development, but also specifics of reflection as intrapersonal formation, closely related to individual identity and self-consciousness.

Keywords: reflection, communication reflection, communication activity, senior preschool age children, system speech disorders.

Подано до редакиії 16.02.2016

Рецензент: д. психол. н., проф. Л. М. Руденко

УДК: 159.922.2:37.015.3

Вікторія Михайлівна Білодіd,

аспірант кафедри психології розвитку, Київський національний університет імені Тараса Шевченка пр. Глушкова, 2-а, м.Київ, Украӥна

\section{ПРАКТИЧНІ РЕКОМЕНДАЦІЇ ЩОДО ФОРМУВАННЯ ЖИТТЕВОЇ ПЕРСПЕКТИВИ СТУДЕНТІВ ЧЕРЕЗ ОРГАНІЗАЦІЮ ОСВІТНЬОГО СЕРЕДОВИЩА}

На основі авторської конщептуальної моделі та результатів емпіричних досліджень обтрунтовано проблематику формування життєвої перспективи під час професійного навчання; запропоновано практичні рекомендаиії щодо шляхів оптимізаџї життєвого проектування через організаџію освітнього середовища, адресовані адміністрації та викладачам вищих навчальних закладів.

Ключові слова: життева перспектива, образ майбутнього, освітня соиіалізаиія.

Постановка проблеми. Здобуття вищої освіти $є$ важливим етапом соціалізації особистості, коли усвідомлено відбувається вибір траєкторій і конструювання моделей майбутньої життєвої перспективи, побудова карти власного життєвого шляху. Під час осві- тньої соціалізації студент засвоює ключові компетенції, що забезпечують адаптацію до вимог актуального для нього середовища (середовища ВНЗ). Водночас, життєва перспектива може бути неузгодженою щодо інших сфер життєдіяльності. Компетенції, необхідні у 
майбутньому (трудова соціалізація, сімейне життя, соціальна взаємодія), постають розмито і віддалено.

Аналіз останніх досліджень і публікацій 3 проблеми. Існує чимало досліджень щодо вдосконалення індивідуальних життєтворчих процесів. Цілісне сприймання власного життєвого шляху, адекватне ставлення до майбутнього вважають важливим критерієм розвитку особистості, її соціальної й психологічної зрілості (Г. О. Балл, З.Г. Кісарчук, С. Д. Максименко, В. Ф. Моргун, О. В. Крюкова, В. Г. Панок, В. В. Рибалка, Л. Д. Тодорів, Н. М. Толстих, 3. О. Шабарова та інші). Описано також окремі елементи життєвої перспективи: життєві цілі та плани, ціннісні орієнтації (Б. С. Братусь,

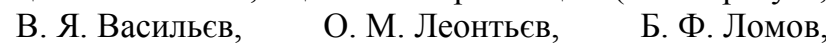
В.Ф. Серенкова та інші). В сучасних та класичних наукових працях достатньо повно розкриті вікові, гендерні, індивідуальні аспекти цього феномену, проте відсутні комплексні дослідження чинників формування життєвої перспективи в період ранньої дорослості, особливо під впливом ситуації освітньої соціалізації у вищій школі.

3 іншого боку, нестабільна соціально-політична ситуація в Україні виступає в ролі фактору середовища, який перешкоджає формуванню життєвої перспективи студентів, змушує молодих людей сумніватися в реалістичності поставлених життєвих цілей та можливостях їх досягнення, перешкоджає ціннісно-смисловому наповненню навчальної діяльності, викликає страх майбутнього. В цій ситуації саме навчальний заклад може виступити тим середовищем соціалізації, що надає студенту впевненості у власних силах та можливості досягнення успіху у майбутньому.

Мета статі - на основі авторської концептуальної моделі та результатів емпіричних досліджень обгрунтувати проблематику формування життєвої перспективи під час професійного навчання i запропонувати практичні рекомендації щодо шляхів оптимізації життєвого проектування через організацію освітнього середовища ВНЗ.

Виклад основного матеріалу дослідження. При реалізації власної мрії від молодих людей потрібне активне позитивне будівництво дорослого життя самостійний вибір життєвої стратегії з урахуванням навколишньої реальності та своїх можливостей. Ми сформулювали концептуальну модель формування узгодженої життєвої перспективи студентів, яка уточнює компоненти впливу освітньої соціалізації.

Життєва перспектива є динамічним образом бажаного або усвідомлюваного майбутнього, що відіграє активуючу, орієнтуючу та прогностичну роль у регуляції діяльності людини. Про сформованість життєвої перспективи свідчить наявність віддалених цілей майбутнього та відповідної програми дій щодо їхньої реалізації (життєвий план). Несуперечлива система ціннісних орієнтацій лежить в основі змістовно та хронологічно погоджених життєвих планів. 3 іншого боку, наявність чіткої життєвої мети та перспектив iii реалізації лежить в основі активності особистості (рис. 1).

Узгоджена життєва перспектива передбачає ряд умов:

- включення майбутнього і минулого життя до контексту актуального теперішнього (цілісність суб'єктивної картини життєвого шляху особистості); водночас - уміння жити «тут і тепер». Життєва перспектива має бути адекватною до пережитого досвіду, але також ефективною і дієвою у відповідності до майбутніх ситуацій життєдіяльності. Баланс цих умов забезпечує здатність до стратегічного управління часом власного життя.

- урахування наявної системи ціннісних орієнтацій особистості (ціннісно-смислова значущість майбутньої часової перспективи $є$ запорукою успішного подолання життєвих труднощів та вирішення криз нереалізованості); водночас - можливість виходу за межі наявної мотиваційної ієрархії. Баланс сталості та динамічності життєвої позиції забезпечує можливість саморозвитку, самореалізації особистості.

- реалістичне усвідомлення комплексу обставин, умов навколишньої дійсності, які створюють напрямки та можливості для оптимального життєвого просування особистості; водночас - розуміння потенціалу власних психологічних характеристик, здатності змінювати умови життєдіяльності та власне майбутнє. Баланс цих умов забезпечує цілеспрямовану суб'єктну активність особистості, готовність до майбутнього в теперішньому.

- уміння особистості не лише усвідомлювати, а й грунтовно вибудовувати структурні елементи життєвої перспективи, оскільки осмислений підхід до формування системи ціннісних орієнтацій, висунення адекватних життєвих цілей, способів їх досягнення, складання планів, програм на майбутнє є надійною основою для реалізації запланованого.

В онтогенезі людина поступово формує уявлення про себе як про діючого в часі суб'єкта, а життєва перспектива постає як певні диспозиції стосовно активності в найбільш актуальних сферах життедіяльності. Формування та коректування складових перспективи відбувається протягом усього життя, особливо в періоди активних соціалізуючих впливів. Кожному новому етапові життєвого шляху відповідає специфічний зміст перспективи, що відображує реальні зміни в умовах довкілля, життєвій ситуації та самій людині. Розділення найближчої та віддаленої життєвої перспективи $є$ важливим новоутворенням юнацького віку, що формується в процесі вирішення завдань самовизначення. Подальше досягнення соціальної зрілості, автономності має місце в тому випадку, коли усвідомлено відбувається вибір траєкторій i конструювання моделей майбутньої життєвої перспективи. Освітня соціалізація забезпечує комплексну ситуацію формування і перевірки життєвої перспективи. 


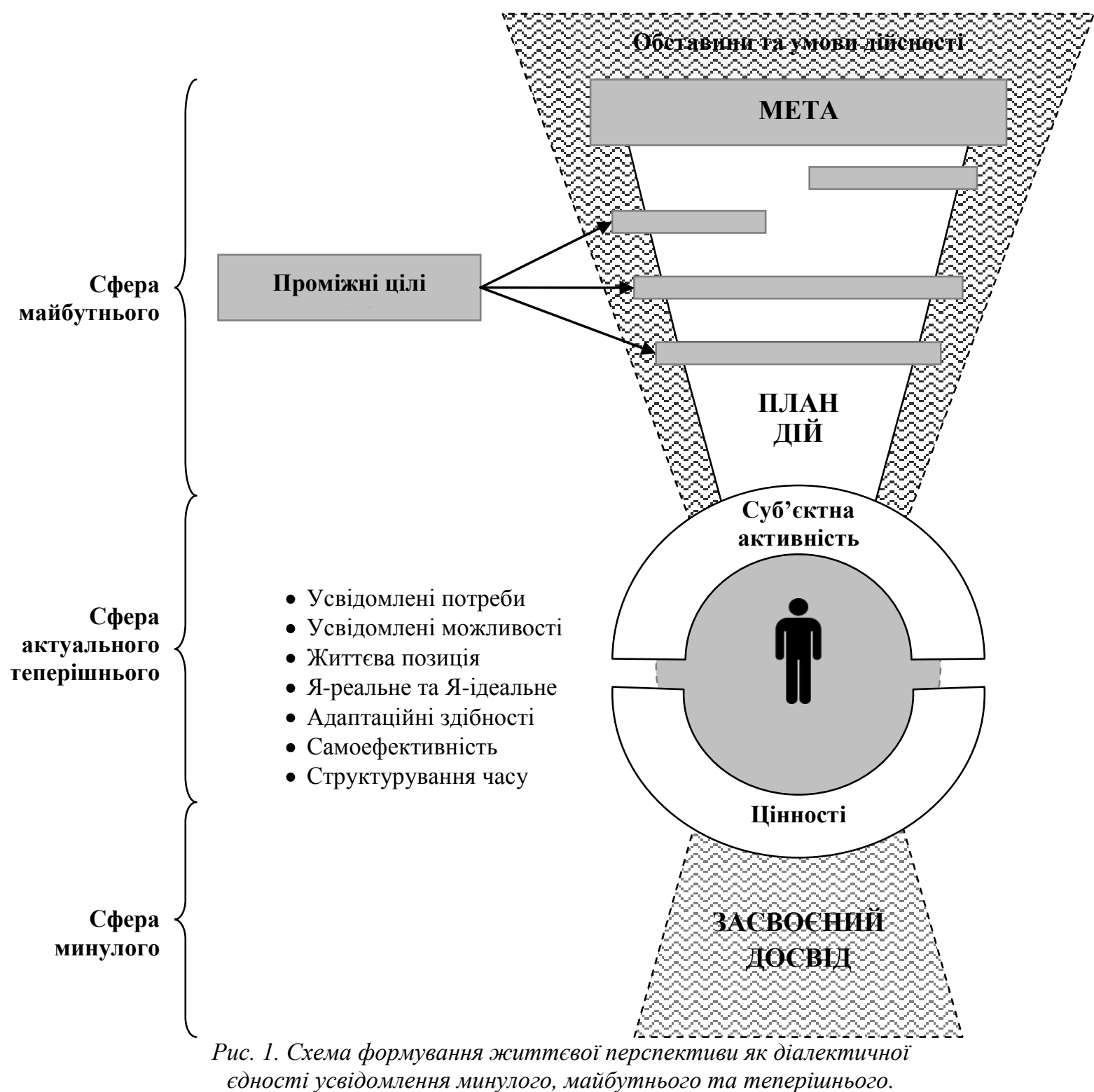

*Джерело: власна розробка автора

Освітня соиіалізація є процесом активного розвитку психіки людини в спеціально організованих педагогічних умовах освітніх установ шляхом цілеспрямованого засвоєння соціокультурного досвіду та стихійного опанування соціальними ролями. Її метою $\epsilon$ набуття студентом професійно важливих знань, умінь та якостей (відповідно до усталеної в соціумі моделі спеціаліста), а також формування загальної життєвої компетентності. В процесі освітньої соціалізації відбувається наближення, розширення та конкретизація (структурування) життєвої перспективи за рахунок фіксації життєвих планів у нових життєвих сферах.

Освітня соціалізація у вищій школі включає цілеспрямовані та стихійні впливи, які діють на макрорівні (глобальні тенденції розвитку освіти в країні та світі), мезорівні (культурне, інформаційне, нормативно- контролююче, організаційно-матеріальне середовище конкретного ВНЗ) та мікрорівні (безпосереднє соціальне оточення студента).

Формування життєвої перспективи під час навчання у ВНЗ здійснюється в два етапи. На першому етапі (I-II курси) їі формування постає як процес та контур реалізації основних життєвих цілей: на фоні інтенсивного пристосування до середовища відбувається смислове наповнення навчальної діяльності, особистісне самовизначення та ідеальне проектування себе в майбутнє. Другий етап (III-VI курси) визначається соціальним самовизначенням в руслі професійної підготовки, формування життєвої перспективи постає як результат із можливою корекцією.

Важливим фактором соціалізації є суб'єктна позиція студента, яка зумовлює вибір ресурсів соціалізації, необхідних для максимально ефективної адап- 
тації та саморозвитку. Аналізуючи ВНЗ сучасної України, варто говорити про наступні компоненти освітньої соціалізації:

1) навчальний - засвоєння ключових компетенцій, залучення індивідів до особливостей реалізації освітніх видів діяльності у вищій школі;

2) середовищний - вплив організаційної культури на рівні університету, факультету, трансляція загальних ідеалів і традицій освіти;

3) інтеракційний - безпосередні взаємодії викладацького складу та студентів один з одним;

4) професіоналізуючий - формування професійної ідентичності.

Ці компоненти в середовищі соціалізуючих впливів активно чи пасивно сприймаються студентом, опосередковуються через його вміння та здібності, особистісні риси, мотиваційну сферу та сферу структурування часу, формуючи особливості життєвої перспективи. В свою чергу, узгоджена життєва перспектива дає змогу при моделюванні бажаного майбутнього зберігати та утримувати баланс між власними домаганнями, мріями, цілями і реаліями актуальної життєвої ситуації.

Під час емпіричного дослідження, в якому прийняли участь 126 студентів Київського національного університету імені Тараса Шевченка, ми встановили три типи особистості, що відрізняються якісними особливостями узгодженості життєвої перспективи і характеристиками впливу освітньої соціалізації: надузгоджені, гармонійні, недостатньо узгоджені. Поширеність представників типів на різних курсах навчання засвідчує неефективний і переважно стихійний процес формування життєвої перспективи під впливом освітньої соціалізації.

У розвитку узгодженості життєвої перспективи студентів найбільш значущими чинниками виявилися професійний та інтеракційний напрямок впливу освітньої соціалізації та активна суб'єктна позиція щодо засвоєння цих впливів. Висока активність студента дозволяє йому з пасивного об'єкта впливів перетворитися на учасника соціалізуючих взаємодій, створює умови для його саморозвитку і констатування життєвих завдань як у майбутній професії, так і загалом у суспільстві.

Експериментальні дані свідчать про можливість ефективно впливати на формування узгодженої життєвої перспективи шляхом спеціальних занять (соціально-психологічного тренінгу). Проте, реалізація такого тренінгу має деякі обмеження у зв'язку з природою досліджуваних змінних. Професійний, інтеракційний, середовищний та навчальний напрямки впливу освітньої соціалізації є такими, що за рахунок тренінгу вплинути на них важко, адже його учасники більше занурені в мікрорівень їх функціонування. Ці змінні функціонують переважно на мезорівні - рівні культурного, громадського, інформаційного, нормативноконтролюючого, організаційного та матеріального середовища конкретного ВНЗ. Тому постала необхідність у розробці практичних рекомендацій щодо формування життєвої перспективи студентів через спеціальну організацію освітнього середовища.

І. Рекомендації для адміністрації та керівників факультетів.

Продуктом процесів професійної освітньої соціалізації повинен стати індивід, готовий до виконання всього спектру життєвих функцій, здатний до формування збалансованої майбутньої перспективи та реалізації іiі складових. Специфікою сучасної освіти $є$ те, що за своєю природою вона повинна мати випереджаючий характер, формуючи особистісні та професійні риси студента, спираючись на певний проект, що містить низку уявлень футурологічного характеру, які слугували б орієнтиром у розбудові стратегії освітніх перетворень [1]. Для ефективного розвитку таких рис у процесі освітньої соціалізації потрібно заздалегідь сформулювати та мати на увазі узагальнений еталонний портрет випускника - ідеальний образ, який би втілював усі цінності, традиції, можливості та переваги конкретного навчального закладу.

Пропонуємо список компонентів, які виступають головними в оцінюванні освітньої компетентності в будь-який сфері:

- комунікативна компетенція (володіння засобами та навичками усної та письмової виразності спілкування на різних мовах, у різних знакових системах, вміння працювати в колективі, вирішувати конфлікті ситуації);

- інформаційна компетенція (володіння актуальними інформаційними та інструментальними технологіями, потенціал засвоєння інновацій в майбутньому; готовність до спільної професійної діяльності, майстерне оволодіння засобами комп'ютеризованої комунікації);

• когнітивна компетенція (потреба в безперервному підвищенні освітнього рівня, усвідомлення меж та ресурсів реалізації свого особистісного потенціалу, здатність самостійно здобувати нові знання та вміння, використовуючи сучасні освітні, інформаційні технології; здатність стимулювати пошук нових ідей та ефективне використання власного досвіду);

- міжкультурна та міжгалузева компетентність знання, вміння та здібності, необхідні для адаптації та продуктивної діяльності в різних професійних спільнотах; встановлення розгалуженої системи зв'язків у межах власної професії;

- загальнонаукова компетенція - застосування основних особливостей наукового світогляду при побудові особистої картини світу; здатність використовувати потенціал загальнонаукових та загальнопрофесійних категорій, понять, принципів та закономірностей в інтелектуальній і професійній діяльності; можливість проводити аналіз проблемних ситуацій, реалізуючи об'єктивний підхід до пояснення суті та істини; критично та раціонально оцінювати нову інформацію, що поступає із зовнішніх джерел.

- соціальна компетенція (здатність взяти на себе відповідальність, спільно виробляти рішення і брати 
участь у їх реалізації, ефективна взаємодія особистих інтересів з вимогами організації);

- персонально-особистісна компетентність (здатність стратегічно осмислювати ресурси, створювати умови для власного фізичного, когнітивного, естетичного, морального, професійного саморозвитку та самовдосконалення);

- спеціальна компетенція (здатність самостійно виконувати професійні дії та критично осмислювати результати своєї праці).

Для створення еталонного образу-моделі доцільно залучати працівників ВНЗ (керівників та провідних викладачів), студентів, а також випускників, які можуть оцінити діяльність навчального закладу саме в перспективі реалізації життєвих цілей. Отриманий таким чином «портрет студента» корисно оформити як статутний документ та популяризувати серед всіх учасників навчально-виховного процесу. Маючи в розпорядженні ідеальну модель особистості, яка є результуючою метою всіх навчально-виховних впливів, слід мати іiї на увазі при прийнятті адміністративних рішень, організації навчального процесу, розподілі матеріальних ресурсів, плануванні виховних заходів тощо. Саме цей образ-мета має лежати в основі дизайну всіх освітніх послуг.

Цілеспрямована соціалізація в системі вищої освіти передбачає не тільки безпосередній вплив на особистість, а формування певним чином організованого освітнього середовища, що дозволяє максимально реалізувати особистісний потенціал студентів. Певний тип поведінки, що розуміється як універсальний, оптимальний заохочується за допомогою системи соціального контролю - норм і санкцій, закріплених у нормативно-правовій документації вищих навчальних закладів. При цьому характер опанування студентами бажаних моделей поведінки часто залишається стихійним, неусвідомленим, неактуальним. Для подолання такого протиріччя необхідно оптимізувати умови i засоби навчально-виховного процесу, щоб покращити управління цілеспрямованою соціалізацією у ВН3. Основними засобами цілеспрямованої соціалізації у вищій школі є зміст освіти, специфіка методики навчання, особливості організації життєдіяльності в даних соціальних організаціях. У системі сучасної освіти перелічені завдання реалізуються за допомогою компетентнісного підходу [1]. Спрямованість вищої освіти на розвиток у студентів професійних компетентностей дає змогу сформувати їх як фахівців, що володіють не лише грунтовними фаховими знаннями, але $є$ здатними та готовими самостійно свідомо визначати, адекватно оцінювати та коректувати власне життя, прагнуть до самовдосконалення, мають розвинене критичне мислення, сформовані навички роботи в команді, уміють упевнено діяти в нестандартних життєвих та професійних ситуаціях, працювати з різними джерелами інформації тощо.

"Наука і освіта", №2-3, 2016
Ефективним способом реалізації компетентністного та особистісного підходу у професійній освіті є система наставництва [8]. Перевага цього методу полягає не тільки в передачі знань у широкому діапазоні практичних можливостей, але й у виховному впливі на особистість. Відповідальний вибір наставників залучає до цієї діяльності спеціалістів 3 найвищим рівнем власного професійного розвитку та безсумнівно цінними особистісними якостями. Саме такий наставник має стати для студента прикладом успішної життєвої реалізації та еталоном образу «Я-професіонал». Особливості взаємодії педагоганаставника під час навчально-виховної роботи зі студентами передбачають розвиток певних психологічних механізмів майбутнього фахівця, які забезпечать йому продуктивне входження, адаптацію, індивідуалізацію та інтеграцію в освітньо-професійні та професійні групи. Тобто забезпечується набуття відповідних системних, інструментальних та особистісних, міжособистісних компетенцій.

У формуванні життєвої перспективи під впливом освітньої соціалізації великий потенціал має підвищення суб'єктної активності студентів, що може проявлятися в наступних формах:

- заохочення академічної мобільності студентів та викладачів, що дає можливість отримати різнобічну освіту за обраним напрямом підготовки, сформувати концепт позитивної свободи особистості, підвищити конкурентоспроможність та життєву підготовленість фахівця;

- надання інформації стосовно системи наукових грантів для вмотивованого пошуку професійних знань та додаткового ціннісно-смислового наповнення навчальної діяльності;

- поширення різних форм наукової комунікації студентів: участь у конференціях, семінарах, форумах, у тому числі віртуальних (формує реалістичне та оптимістичне уявлення про власні вміння та можливості як в професійній, так і в науково-дослідницькій діяльності);

- активація викладацького складу стосовно виходу за рамки установлених навчальних програм (факультативи, які дають студентам можливість реалізувати актуальні навчальні запити і потреби);

- визнання пріоритетів самостійного вибору студентом навчальних дисциплін та планів їх вивчення;

- посилення аспектів освітньої соціалізації, спрямованих на усвідомлення молодими людьми своєї ролі і місця в суспільстві як соціокультурній основі подальшого життєвого розвитку (студентське самоврядування, громадська та волонтерська діяльність, формування здорового способу життя тощо);

- організація спеціальних семінарів для викладачів з метою підвищення їх педагогічної майстерності у застосуванні проблемно-орієнтованого, компетентнісного та особистісного підходів, впровадженні навчальних програм у формі освітнього діалогу, використанні розвивальних технологій, створенні імітаційної моделі професійної діяльності; 
- сприяння інноваційності та випереджувальний характер професійної освіти; створення структур, які б дієво допомогли студентам середніх та старших курсів у самоуправлінні кар'єри та використовували маркетингові інструменти оптимізації кар'єрного ресурсу випускників за умов конкуренції на ринку праці (Кар'єрне бюро) [7].

Окрім засвоєння системи професійних знань та вмінь, що складає основний зміст вищої освіти, під час навчання у ВНЗ формується ще один важливий ресурс життєвого успіху особистості - розгалужена система соціальних зв'язків та контактів, які супроводжують людину протягом всього наступного дорослого життя. У вітчизняній системі освіти цей процес переважно має стихійний характер, але адміністрація навчальних закладів може сприяти інтеракційній згуртованості студентів через організацію позанавчальних масових заходів, а також популяризацію позитивного образу «Я-студент (назва вищу)» та створення атмосфери обраності, елітарності, яка б об'єднувала всіх студентів та випускників закладу.

II. Рекомендації для викладачів предметних дисциплін.

При розробці навчальних дисциплін треба брати за основу компетентнісний підхід та спрямовувати навчальні завдання на розвиток ключових компетенцій студентів. Важливим критерієм результату засвоєння дисципліни згідно із цим підходом є здатність людини діяти в проблемних ситуаціях професійної діяльності. Для цього в структуру навчальних курсів необхідно включати професійно-орієнтовані проблемні завдання; на конкретних прикладах розглядати особливості використання набутих теоретичних знань у ситуаціях майбутньої діяльності (метод кейсів); детально пояснювати, в яких саме видах діяльності та в якій саме формі отримані при засвоєнні конкретної теми знання і вміння можуть бути реалізовані студентом вже зараз. Отже, застосування основних принципів компетентнісного підходу у ВНЗ вимагає від викладача розширення діапазону педагогічного впливу із трансляції системи знань 3 конкретного предмету на формування загальної компетентності особистості студентів.

Вирішення спеціально поставлених практичних i дослідницьких завдань, спрямованих на застосування отриманого раніше і набуття нового досвіду в процесі педагогічної взаємодії із студентом, є умовою формування компетенцій. 3 цієї точки зору, при викладанні будь-якої дисципліни зміщається акцент $з$ простого накопичення студентом знань, що необхідні для майбутньої професійної діяльності, на організацію особистісних знань у певні структури, що дозволяють максимально ефективно пристосовуватися до середовища. В результаті з'являється складна динамічна структура. Така гнучка організація знань дозволяє не просто їх зберігати та накопичувати, а критично переосмислювати всю їх систему при появі нової інформації, вказувати на їх дефіцит у певних сферах, оновлювати запит на них відпо- відно до найбільш актуальних освітніх, соціальних, професіональних змін, що сприяє формуванню суб'єктної позиції щодо процесу навчання.

Дуже актуальним та корисним в умовах сучасної вищої освіти є створення викладачем електронної підтримки власної дисципліни. Це дозволяє зберігати відібрані викладачем інформаційні ресурси та робити їх доступними для студентів. Така можливість суттєво збільшує потенціал самостійної роботи студентів та розвиває відповідні навички планування та структурування життєвих завдань у майбутньому.

Гуманістичні ідеали викладання підкреслюють вагомість особистості педагога: відбір, підготовка, форма подання, засоби і методики, що застосовуються в освітньому процесі - всі ці процедури проходять крізь фільтр суб'єкта педагогічної діяльності. Така включеність породжує взаємодію і спонукає студентів відповідати на неї вже на рівні свого особистісного сприймання. Розуміння значущості такої особливої атмосфери освітнього процесу, з одного боку, вимагає відповідального та свідомого ставлення викладачів до своєї діяльності, з іншого - розширює можливості формуючого впливу на студента як на представника суспільства майбутнього.

Загальною рекомендацією для саморозвитку педагогів ВНЗ є поєднання викладацької діяльності з професійною практикою. Саме це дає викладачеві реалістичне уявлення про знання та вміння, необхідні для виконання професійної діяльності, способи їх реалізації в певних ситуаціях; дозволяе практично перевірити та відібрати в якості навчального матеріалу найбільш актуальні теми, теорії та інструменти; допомагає конкретизувати роль окремих компонентів навчального процесу у становленні особистості майбутнього фахівця. В свою чергу, все це допомагає сформувати більш реалістичну життєву перспективу студентів стосовно реалізації професійних цілей.

3 цією ж метою рекомендуємо керівникам кафедр та факультетів залучати до викладання спеціальних предметів (або окремих тем, лекцій) спеціалістівпрактиків, які мають реальні здобутки та авторитет у професійній спільноті.

III. Рекомендації для кураторів груп та спеціалістів з виховної роботи:

1. Ввести у виховну роботу елементи тренінгових занять $з$ формування узгодженої життєвої перспективи студентів. Для студентів молодших курсів головною метою має стати оптимізація та інтенсифікація адаптаційного процесу, швидке включення в соціалізуюче середовище вищої школи, засвоєння якомога більш широкого діапазону соціальних ролей в ньому. Для студентів старших курсів - сприяння ефективному професійному самовизначенню (знаходження власної спеціалізації всередині професії, яка б дозволила досягти життєвих цілей з урахуванням наявних здібностей, інтересів та вмінь), усвідомленому цілепокладанню. На кожному етапі навчання необхідно переструктуровувати сформовані життєві завдання відповідно до актуальної ситуації професійного та особистісного розвитку. 
2. Проводити моніторинг психологічного стану студентів у контексті вирішення особистісних криз, які наявні в період професійного навчання.

У більшості студентів під час професійного навчання зміцнюється впевненість у зробленому професійному виборі та йде неусвідомлений процес кристалізації професійної спрямованості особистості. Поступове засвоєння майбутньої соціально-професійної ролі сприяє самопроектуванню студентом себе як представника певного професійного співтовариства. Однак, багато студентів переживають незадоволеність i розчарування в зробленому (вимушено або за бажанням) виборі навчально-професійного поля. В такому випадку необхідно своєчасно внести корективи у професійний старт.

Слід мати на увазі типові труднощі та кризи, характерні для кожного з етапів освітньої соціалізації та професіоналізації (за Е. Ф. Зеєром, Г. К. Радчук, Н. Ф. Шевченко, Н. С. Пряжниковим та ін.), а також намітити завдання, які стоять перед педагогами в цьому контексті $[2 ; 5 ; 9 ; 4]$ :

1. Початок навчання характеризується відсутністю цілісності образу професійного самовизначення (в ситуації вибору ВНЗ під впливом випадкових обставин); низькою якістю прийнятого і реалізованого рішення (на початку навчання виявляються факти, які не було враховано раніше); поверхневим уявленням про обрану професію, цілі, зміст і засоби майбутньої професійної діяльності, про професійно важливі якості, варіанти і особливості майбутньої трудової зайнятості; поганим розумінням себе, власних можливостей, цінностей, бажань, характеру; невиразним баченням (відсутністю) освітньої та професійної перспективи та плану освоєння професії.

На першому році навчання становлення професійної свідомості характеризується конфліктом неузгодженості, що стимулює пізнавальну активність студентів, створюючи підгрунтя для породження нових професійних сенсів. На другому курсі навчання спостерігається стрімке падіння значущості більшості цінностей студентів, що свідчить про ціннісну освітню кризу, яка характеризується аномією і відображає ситуацію ослаблення впливу соціальних норм унаслідок фрустрації очікувань студентів щодо можливостей їх самореалізації у рамках ВНЗ, що призводить до переживання відчуженості від формального змісту освіти та знеособлення.

У цей період викладачі покликані допомогти остаточно завершити становлення професійного самовизначення, разом зі студентами аналізувати бажання, можливості і суспільне значення обраної професії; виокремити специфічні особливості професії, що роблять іiі цікавою, неповторною, такою, що забезпечує творчий розвиток; які ресурси, статус, можливості впливу має професія на соціальне та особисте життя. На цьому ж етапі уточнюється прийняте рішення. Студент повинен освоїти способи самопізнання, ви- явити особисті вагомі переваги, виявити свої професійно важливі якості, а також індивідуальні обмежувачі, що перешкоджають майбутньому професійному успіху. Навчивши його прийомам створення когнітивної карти професії для розуміння своїх перспектив в ній, можна допомогти подолати всі труднощі першого етапу, створити умови для появи бажання стратегічно планувати власну кар'єру. Поява стійкої внутрішньої мотивації на продовження професійного навчання, оптимістичний погляд на майбутнє успішне робоче поле - це критерії подолання труднощів цієї стадії.

2. Занурення в особливості обраної спеціальності характеризує другий етап. Його проходження може бути пов'язане із рядом перешкод: туманне уявлення життєвих і професійних цілей, відсутність розгорнутого плану кар'єри; зниження значущості смисложиттєвих орієнтацій, розмитість і недиференційованість професійної ідентичності; проблеми із побудовою власної стратегічної кар'єрної лінії; відсутність або несформованість певних професійно важливих якостей; несформованість соціально схвалюваних і ділових якостей; сумніви щодо рівня власної професійної майстерності.

На III курсі виникає криза професійної підготовки [4], яка виявляється у конфлікті контекстів, при якому сформована система значень $є$ недостатньою для виконання квазіпрофесійної діяльності. Викладачі в рамках проходження цієї стадії мають надати допомогу студентам за такими векторами: вдосконалення вмінь критичного мислення соціально зумовлених якостей; виявлення рівня розвитку професійно значущих якостей, їх вдосконалення, розбудова найбільш ефективного індивідуального стилю діяльності; стратегічне кар'єрне планування; формування вміння рефлексії власної діяльності з позиції професіонала; пошук максимально адаптивних способів освоєння професії та входження в професійне середовище; підвищення рівня пристосування до ситуації невизначеності; орієнтування в діловому спілкуванні, особливо в конфліктних взаємодіях. Загалом завдання другого етапу покликані сформувати образ «ідеального» спеціаліста та засвоїти основні прийоми та техніки досягнення цього бажаного рівня професіоналізму.

3. «Заключні» курси навчання, закінчення ВНЗ та подальше працевлаштування (або продовження освіти) зумовлюють виникнення таких труднощів: невідповідність (відсутність) стратегії майбутнього працевлаштування; низький рівень адаптації до мінливих умов ринку праці; відсутність реалістичної інформації стосовно особливостей функціонування сфери професійної зайнятості конкретного середовища; неготовність швидко та ефективно пристосовуватися до справжньої професійної діяльності.

Ha IV-V курсах у студентів виникає кризовий етап, тісно пов'язаний з перебудовою життєвої перспективи [9]. Ha IV курсі з'являється переживання «внутрішнього смислового конфлікту» - зіткнення наукових смислів, що сформовані на попередніх етапах навчання, та практич- 
них смислів, набутих упродовж виробничої практики. У цьому конфлікті виявляється протиріччя між роздрібненістю знань за багатьма навчальними дисциплінами й можливістю системного використання цих знань у майбутній трудовій діяльності. При традиційній системі підготовки на V курсі це протиріччя зберігається за основними показниками, що свідчить про значне послаблення формуючого впливу навчання на становлення професійної свідомості випускників.

Серед студентів-випускників спостерігається тенденція до розчарування у виборі професії, яка $є$ результатом трансформації стереотипних образів професії в індивідуальні уявлення про неї [3]. Спад захопленості професією і розчарування в ній також можуть бути викликані поступовим усвідомленням усіх складнощів професії. Криза сенсожиттєвих орієнтацій студентів випускного курсу проявляється у значущому зниженні показників загальної осмисленості життя, майбутнього та локусу контролю Я; десинхронізацією всіх темпоральних локусів, що проявляється у нездатності сформулювати життєві цілі, дезорієнтованості щодо свого майбутнього. Можливою причиною такої кризи може бути невідповідність зовнішніх

\section{ЛІТЕРАТУРА}

1. Бермус А. Г. Проблемы и перспективы реализации компетентностного подхода в образовании [Электорнный ресурс] / А. Г. Бермус. - Режим доступа: www.eidos.ru/journal/2005/0910-12.html.

2. Зеер Э. Ф. Психология профессионального образования : учебное пособие / Э. Ф. Зеер. - Екатеринбург, 2000. - $386 \mathrm{c}$.

3. Міхно К. О. Динаміка уявлень студентівпсихологів про майбутню професію : автореф. дис. на здобуття наук. ступеня канд. психол. наук : спец 19.00.07 / К. О. Міхно. - К., 2008. - 19 с.

4. Пряжников Н. С. Психология труда и человеческого достоинства / Н. С. Пряжников, Е. Ю. Пряжникова. - М. : Академия, 2005. - 216 с.

5. Радчук Г. К. Психологія аксіогенезу особистості у контексті вищої професійної освіти : автореф. дис. на здобуття наук. ступеня д-ра психол. наук:

\section{REFERENCES}

1. Bermus, A. G. Problemy i perspektivy realizatsii kompetentnostnogo podkhoda $v$ obrazovanii [Problems and prospects for the implementation of the competence approach in education]. Retrieved from: www.eidos.ru/journal/2005/0910-12.html [in Russian].

2. Zeer, E. F. (2000). Psikhologiya professionalnogo obrazovaniya : uchebnoe posobie [Psychology of vocational education: tutorial]. Ekaterinburg [in Russian].

3. Mikhno, K. O. (2008). Dynamika uiavlen studentivpsykholohiv pro maibutniu profesiiu [Dynamics of studentspsychologists' vision of future profession]. Extended $a b$ stract of candidate's thesis. Kyiv [in Ukrainian].

4. Pryazhnikov, N. S., \& Pryazhnikova, E.Yu. (2005). Psikhologiya truda i chelovecheskogo dostoinstva

"Наука і освіma", №2-3, 2016 соціально-економічних обставин і внутрішніх потреб та цінностей випускників.

Цей період ставить перед педагогами наступні завдання: перевірка на актуальність кар'єрного плану по відношенню до реальних умов ринку праці; проведення практичних занять із розігруванням ситуацій, пов'язаних із пристосуванням до робочого місця та колективу; аналіз особливостей розвитку та функціонування сучасного ринку праці. Успішне проходження цього етапу дозволяє студентам сформувати уявлення щодо професійної реалізації та сформувати чіткий план дій щодо розбудови кар'єри в актуальних для них умовах та вимогах сучасного професійного середовища.

Висновки та перспективи подальших досліджень. Були сформульовані практичні рекомендації щодо формування життєвої перспективи студентів через організацію освітнього середовища, адресовані адміністрації вищих навчальних закладів, викладачам навчальних дисциплін та спеціалістам 3 виховної роботи. Ми вважаємо найбільш перспективним напрямом подальшого дослідження перевірку реальних ресурсів та можливостей трансформації освітнього простору на різних рівнях його функціонування.

спец. 19.00.07 / Г. К. Радчук ; НААН України, Ін-т психології ім. Г.С. Костюка . - К., 2011. - 41 с.

6. Свириденко Д. Б. Академічна мобільність: відповідь на виклики глобалізації: монографія / Д. Б. Свириденко. - К. : Вид-во НПУ імені М.П. Драгоманова, 2014. - 279 с.

7. Ходкинсон Дж. П. Компетентная организация : психологический анализ процесса стратегического менеджмента / Дж. П. Ходкинсон, П. Сперроу. - Х. : Гуманитарный Центр, 2007. - 392 с.

8. Чугаєва Н. Ю. Успішна соціалізація студентів ВН3 як основна мета діяльності педагога-наставника / Н. Ю. Чугаєва // Актуальні проблеми психології: зб. наук. пр. - 2012. - Т. ХІІ, Вип. 14. - С. 284-291.

9. Шевченко Н. В. Вища освіта як механізм формування кар'єрного ресурсу спеціаліста : автореф. дис. на здобуття наук. ступеня канд. соціол. наук : спеціальність 22.00.04 / Н. В. Шевченко; Харк. нац. ун-т внутр. справ. - Х., 2007. - 17 с.

[Psychology of labor and human dignity]. Moscow : Akademiya [in Russian].

5. Radchuk, H. K. (2011). Psykholohiia aksiohenezu osobystosti u konteksti vyshchoi profesiinoi osvity [Psychology of axiological genesis of personality in the context of higher professional education]. Extended $a b$ stract of Doctor's thesis. Kyiv: NAAN Ukrainy, In-t psykholohii im. H.S. Kostiuka [in Ukrainian].

6. Svyrydenko, D. B. (2014). Akademichna mobilnist: vidpovid na vyklyky hlobalizatsii: monohrafiia [Academic mobility: the challenges of globalization: monograph]. Kyiv: Vyd-vo NPU imeni M.P. Drahomanova [in Ukrainian].

7. Khodkinson, Dzh. P., \& Sperrow, P. (2007). Kompetentnaya organizatsiya : psikhologicheskiy analiz prot- 
sessa strategicheskogo menedzhmenta [The competent organization : a psychological analysis of the process of strategic management]. Moscow : Gumanitarnyy Tsentr [in Russian].

8. Chuhaieva, N. Yu. (2012). Uspishna sotsializatsiia studentiv VNZ yak osnovna meta diialnosti pedahoha- nastavnyka [Successful socialization of university students as the main purpose of the teacher-mentor's activities]. Aktualni problemy psykholohii: zb. nauk. pr. - Urgent problems of psychology: collection of scientific works, XII, 14, 284-291[in Ukrainian].

\section{Виктория Михайловна Белодед, аспирант кафедры психологии развития, Киевский национальный университет имени Тараса Шевченко, пр. Глушкова , 2-а, г. Киев, Украина}

\section{ПРАКТИЧЕСКИЕ РЕКОМЕНДАЦИИ ПО ФОРМИРОВАНИЮ ЖИЗНЕННОЙ ПЕРСПЕКТИВЫ СТУДЕНТОВ ЧЕРЕЗ ОРГАНИЗАЦИЮ ОБРАЗОВАТЕЛЬНОЙ СРЕДЫ}

На основе авторской концептуальной модели и результатов эмпирических исследований обоснована проблематика формирования жизненной перспективы во время профессионального обучения; предложены практические рекомендации относительно путей оптимизации жизненного проектирования через организацию образовательной среды. Цель статьи - на основе авторской концептуальной модели и результатов эмпирических исследований обосновать проблематику формирования жизненной перспективы во время профессионального обучения и предложить практические рекомендации относительно путей оптимизации жизненного проектирования через организацию образовательной среды ВУЗА. Жизненная перспектива определяется как динамический образ желаемого или понимаемого будущего, которое играет активирующую, ориентирующую и прогностическую роль в регуляции деятельности человека. Показано, что в процессе образовательной социализации происходит приближение, расширение и конкретизация жизненной перспективы за счет фиксации жизненных планов в новых жизненных сферах; описаны этапы формирования жизненной перспективы во время обучения в ВУЗе. Важным фактором социализации предстает субъектная позиция студента, которая предопределяет выбор ресурсов социализации, необходимых для эффективной адаптации и саморазвития. Выделенны компоненты образовательной социализации: учебный, средовой, интеракциональный, профессионализующий. Эти компоненты в среде социализирующих воздействий активно или пассивно воспринимаются студентом, опосредуются через его умения, способности, личностные черты, мотивации и сферу структурирования времени, формируя особенности жизненной перспективы. Мы можем эффективно влиять на формирование согласованной жизненной перспективы путем социально-психологического тренинга. Однако реализация такого тренинга имеет ограничения, ведь его участники погружены в микроуровень функционирования социализирующих воздействий. Профессиональное, интеракциональное, средовое и учебное направления влияния образовательной социализации функционируют преимущественно на мезоуровне - уровне культурной, общественной, информационной, нормативно-контролирующей, организационной и материальной среды конкретного ВУЗа. Поэтому существует необходимость в целенаправленной организации и трансформации образовательной среды для содействия формированию жизненной перспективы студентов. Соответствующие рекомендации для администрации и руководителей факультетов описывают обобщенный портрет выпускника - эталонный идеальный образ, проект формирования личности, который воплощает ценности, традиции, возможности конкретного учебного заведения (предложены конкретные направления создания такого образа на основе компетентностной модели). Подчеркнуто, что направленность высшего образования на развитие у студентов профессиональных компетенций позволяет сформировать специалистов, которые готовы самостоятельно определять, адекватно оценивать и корректировать собственную жизнь. Намечены практические пути повышения субъектной активности студентов. Рекомендации для преподавателей предметных дисциплин направляют дидактическое планирование на развитие ключевых компетенций студентов. Рекомендации для специалистов по воспитательной работе описывают мониторинг психологического состояния студентов в контексте решения специфических личностных кризисов, которые имеются на каждом курсе профессионального обучения.

Ключевые слова: жизненная перспектива, жизненный план, образовательная социализация, компетенция.

Viktoriia Bilodid, post-graduate student, Department of Developmental Psychology, Taras Shevchenko National University of Kyiv, 2a, Hlushkov Avenue, Kyiv-03680, Ukraine

PRACTICAL RECOMMENDATIONS ON THE FORMATION OF LIFE PROSPECT OF STUDENTS THROUGH THE ORGANIZATION OF EDUCATIONAL ENVIRONMENT

Based on the author's conceptual model and empirical research results, the range of problems of the formation of life prospects during professional training is substantiated; practical recommendations on the ways to optimize life projecting by means of the educational environment organization are suggested. Basing on the author's conceptual model and the results of the empirical research, the article is aimed at substantiating the range of problems of the formation of life perspective during professional training; as well as suggesting practical recommendations on the ways to optimize life projecting by organizing educational environment of a higher educational institution. Life prospect is defined as a 
dynamic image of the desired or conscious future that plays activating, directing and prognostic role in human activity regulation. It is shown that in the process of educational socialization approaching, extension and specification of life prospect takes place by fixing life plans in new spheres of life. The stages of life perspective in the course of study at a higher educational institution are described. An important socialization factor is subjective position of a student, which conditions the choice of socialization resources required for the effective adaptation and self-development. The following components of the educational socialization are singled out: educational, environmental, interactive, and professionalizing. These components are passively perceived by a student, mediated through his/her skills, abilities, personality traits, motivation and scope of structuring time, forming features of life prospect. One can effectively influence the formation of the coordinated life prospect by social and psychological training. However, the implementation of such a training has limitations because its members are immersed in the microlevel of functioning of socializing influences. Professional, interactive, environmental and educational direction of impact of educational socialization function mainly at the mesolevel - the level of cultural, social, informational, regulatory and supervisory, organizational and material environment of a particular higher educational institution. Therefore, there is a need for the purposeful organization and transformation of the educational environment in order to promote life prospects of students. The relevant recommendations for the administration and heads of departments describe a generalized portrait of a graduate - ideal reference image, personality formation project that embodies values, traditions and opportunities of a specific educational institution (specific areas to create such an image based on the competency model are suggested). It is emphasized that focus of higher education on the development of the professional competencies of students enables forming professionals ready to determine themselves, adequately assess and adjust their own lives. Practical ways to enhance the subject activity of students have been outlined. The recommendations for lecturers of subject disciplines direct didactic planning to be focused on the development of key competencies of students. The recommendations for specialists in educational work describe monitoring of the psychological condition of students in the context of solving specific personal crises that arise during each course of professional training.

Keywords: life prospect, life plan, educational socialization, competence.

Подано до редакиіï 20.02.2016

Реиензент: д. психол. н., проф. О. І. Власова 